\title{
ANTHONY NETTING
}

\section{Images and Ideas in Russian Peasant Art}

A close look at Russian peasant art yields two divergent impressions. The profusion of styles and techniques is amazing, testimony to the ready creativity of peasant craftsmen. But throughout this wealth of invention, a constant tone prevails: the images portrayed are few and everywhere much the same. ${ }^{1}$

Two images predominate: the sun, at times accompanied by flowers, birds, and animals; and a flowering tree (drevo zhizni) or a woman raising her arms, with two figures, often armed men on horseback, at either side. Most designs in peasant art involve one of these persistent images. ${ }^{2}$ The concern of the present paper is to explore what they may have meant.

Both basic images are ancient. B. A. Rybakov and other archaeologists have shown that virtually identical designs appeared on artifacts of the Sarmatian and Scythian periods in South Russia. ${ }^{3}$ The same images continue in various forms in the clecorative art of pre-Mongol Rus'. The female figure flanked by horsemen appears repeatedly from the sixth century A.D., the beginning of the historical Slavic period in Russia. ${ }^{4}$

1. V. S. Voronov, Krestianskoe iskusstvo (Moscow, 1924), p. 43; I. Ia. Boguslavskaia, "O transformatsii ornamental'nykh motivov, sviazannykh s drevnei mifologiei, v russkoi narodnoi vyshivke," Report to the Seventh International Congress of Anthropological and Ethnographic Sciences held at Moscow, 1964, p. 8.

2. The primary material for this essay was the decorations on articles of wood, bast or bark formerly used by the peasants of north and central Russia-notably some six hundred prialki (distaffs) examined directly or through photographs and descriptions. Some use was also made of peasant designs in other materials: weaving, embroidery, woodcuts ( $h u b k i$ ), enamel and metalware, bone carving, and so forth.

3. See the seminal essay of V. A. Gorodtsov, "Dako-sarmatskie religioznye elementy v russkom narodnom tvorchestve," Trudy gosudarstvennogo istoricheskogo muzcia (Moscow, 1926), pp. 7-36; and the later studies of B. A. Rybakov, "Drevnie elementy v russkom narodnom tvorchestve," Sovetskaia etnografia, 1948, no. 1, pp. 90-106, and his "Prikladnoe iskusstvo i skul'ptura," Istoriia kul'tury drevnci Rusi: Domongol'skii pcriod, vol. 2: Obshchestvennyi stroi i dukhovnaia kul'tura (Moscow-Leningrad, 1951), pp. 396-464; L. A. Dintses, "Drevnie cherty v russkom narodnom iskusstve," ibid., pp. 465-91; A. K. Ambroz, "O simvolike russkoi krest'ianskoi vyshivki arkhaicheskogo tipa," Sovetskaia arkheologiia, 1966, no. 1, pp. 61-76, translated in Soviet Anthropology and Archcology, 6, no. 2 (1967) :22-37.

4. Rybakov, "Prikladnoe iskusstvo," p. 399. In the peasant art of neighboring Poland,

I am indebted to the International Research and Exchanges Board and the FulbrightHays Faculty Research Program for support of the research underlying this article. I should also like to express my appreciation to the Soviet scholars, museum curators, and researchers, for their generous assistance in examining collections of peasant artifacts. 


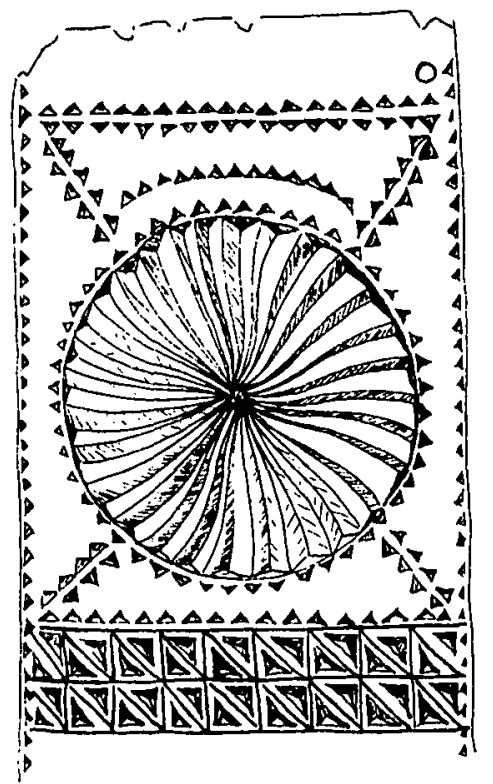

(a)

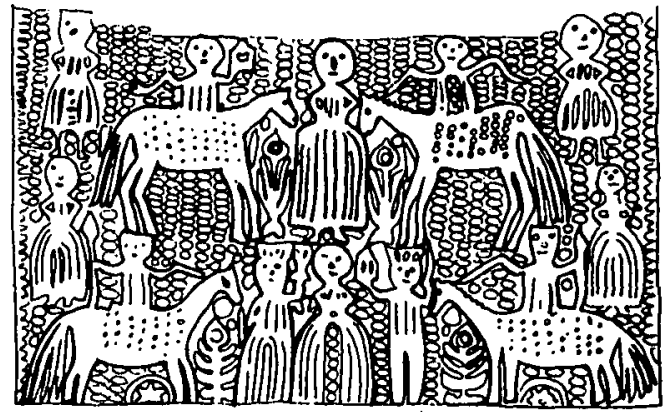

(b)

Fig. 1. (a) Prialka, Shenkurskii uezd, Arkhangel'skaia guberniia. After Iurii Arbat, Puteshestviia za krasotoi (Moscow, 1966), illus. following p. 176. (b) Naboinaia doska. After V. S. Voronov, Krestianskoe iskusstvo (Moscow, 1924), p. 25.

In later centuries the old inages were sometimes much disguised. They became overgrown with decorative detail, or receded into a corner of the design. But their place in the pattern should not be taken as the only measure of their significance. Too idolatrous to openly dominate the art of a Christian people, they may still have operated as secret signs, which invested an entire picture with a familiar value.

Where the old forms do remain central to the design, they commonly come clothed in modern dress. The erstwhile goddess wears a crinoline skirt. Horsemen stand in their traditional pose, decked out in the fashions of the Alexandrine era, with three-cornered cockades or top hats, and muskets in

some similar images appear, but much subdued, obscured by Christian and secular urban themes. See O. A. Gantskaia, Narodnoc iskusstvo Pol'shi (Moscow, 1970). But neither image was limited to the Slavic cultural area. Ambroz (p. 69) notes the goddess motif on archaic Greek vases. I came across a similar design in the folk weaving of modern Bihar, hardly surprising since the mother or tree goddess has been prevalent in Indian art as far back as Harappan times. See Richard Lannoy, The Speaking Tree (New York, 1971), pp. $x x v, 9,22$, plate 7, and passim. The image appears most conspicuously in the art of the ancient Fertile Crescent as far back as the earliest Babylonian dynasties. See Goblet d'Alviella, The Migration of Symbols (New York, 1956 [Reprint of 1894 ed.]), pp. 118-76. Whether the goddess-tree with her acolytes came to Russia from the Near East or arose indigenously is a moot point. Clearly she appealed to a wide range of agrarian cultures. 
hand. Or the whole tableau is domesticated; husband. and wife face each other across a samovar. Through all these mutations, which the plasticity of the original forms facilitated, the modern designs are visibly akin to the old. As late as the Revolution and for some years after, it was only stray works of folk art that wholly lost touch with the old circle of images.

The presence of the old forms has raised a major problem of interpretation. Since Gorodtsov first pinpointed the persistence of archaic emblems in peasant embroidery over forty years ago, Soviet scholars have recognized the widespread survival in modern peasant art of forms and images from the distant past. But almost in one voice, and with some asperity, they have concluded that the peasants had forgotten the old meaning of these elements and repeated them purely out of habit or for decoration.

But the viability of the traditional forms casts doubt on this interpretation. At first glance cut and dried, the old forms come to life when followed through a series of designs. They are not merely copied, but playfully rearranged in new costumes and new settings. ${ }^{5}$ And the images themselves change, shifting places, growing and dissolving into each other through myriad transitional forms. Suns put out petals, blossoms align into a tree, horses turn into roosters. The apparently fixed motifs flow together, as though all were regarded as avatars of a single spirit.

So the peasants saw their art, not as select objects set in a museum case, but as a host of images in motion. On ceremonial occasions especially they had before them an array of kindred designs, theirs and their neighbors', new and worn, expert and homemade. The variations fused into a montage, delivering a composite impression.

Continually turning in the peasant imagination, the ancient forms in later art never look old. Whether done by a master craftsman, or crudely by a local imitator, they come out clear and fresh. They enclured because the peasants took care that they should.

Undoubtedly, peasant artists, to some extent, did work by habit, following conventions handed down to them. But habits, as cliverse schools of psychology agree, fade away unless they are continually reinforced. Erik Erikson has put it well for the historian: "Values clo not persist unless they work, economically, psychologically, and spiritually." "The old peasant images, per-

5. Compare this insouciance in peasant art with formal Christian symbols, and especially with the official conventions of icon painting and the rigid mestnichestvo of the ikonostas.

6. Childhood and Socicty (New York, 1950), p. 121. Both the obvious freshness of the ancient images in later peasant art, and the impossibility of their surviving as mere habits without meaning, have been recognized by recent Soviet researchers. See T. M. Razina, Russkoc narodnoe trorchestio (Moscow, 1970), pp. 136-38. But even Razina, hampered by an outlook more aesthetic than historical, slips back into the groove and concludes that 


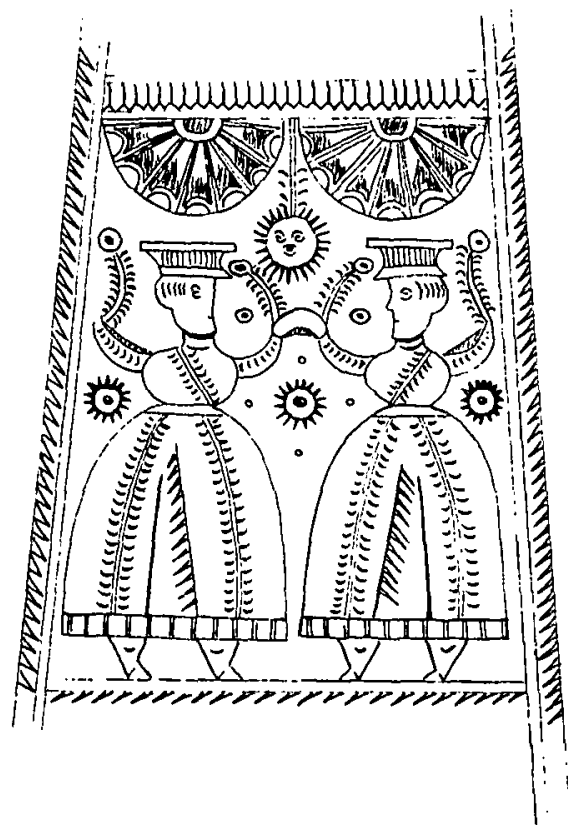

(a)

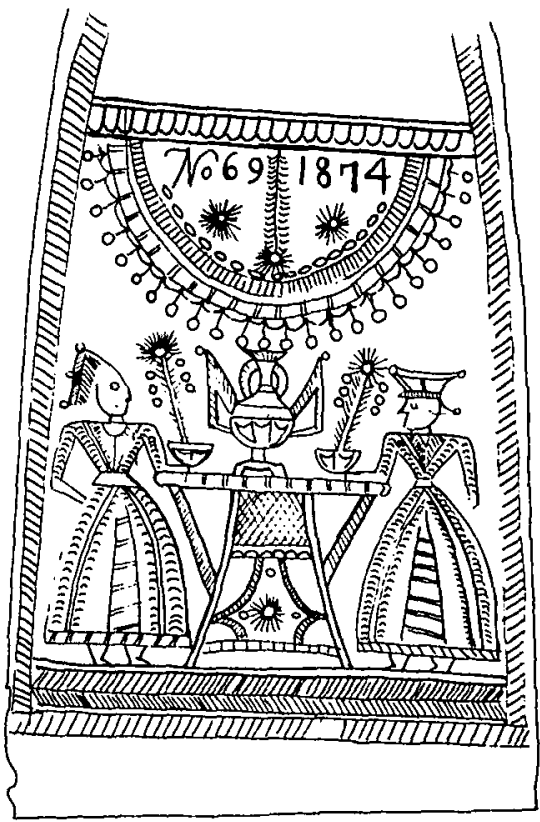

(b)

Fig. 2. (a) Detail of prialka-terem, Iaroslavskaia guberniia. After N. V. Taranovskaia and N. V. Mal'tsev, Russkie prialki (Leningrad, 1970), plate 24. (b) Detail of prialkaterem, Iarovslavskaia guberniia. After V. S. Voronov, Narodnaia rez'ba (Moscow, 1925), illus. 5 .

sisting through a kaleidoscope of styles and techniques, must have continued to work-to have meaning.

Indeed, in certain instances, where a given style was stabilized for a generation or so, contemporary motifs began to dissolve while the old forms took on new life. The intricately carved prialki from northeast Yaroslav guberniia, the teremkovye or tower-house prialki, provide a clear example of this process.

The earliest prialki, dating from the end of the eighteenth century, show a clock tower carved in close detail. It was presumably the tower of the Petropavlovskaia Krepost', which impressed the Yaroslav peasant craftsmen ("pitershchiki") who came to work in the new capital. Below the tower were carved two scenes, usually of figures at a table sipping wine or tea.

Before long the tower began to lose its sharpness, eventually eroding down to a mere outline. The parlor drinking scenes persisted, though in the area around Danilov the cavaliers at their wine were supplanted by roosters

the peasants were overcoming the old images, transforming them into decorative motifs or into more realistic designs (ibid., pp. 138-42, 146).

7. S. K. Zhegalova, "Khudozhestvennye prialki," in Zhegalova et al., Sokrovishcha russkogo narodnogo iskusstva: Rez'ba i rospis' po derezn (Moscow, 1967), D. 137. 


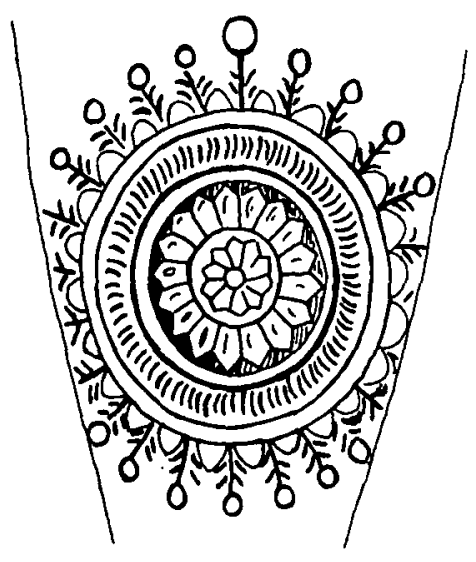

(a)

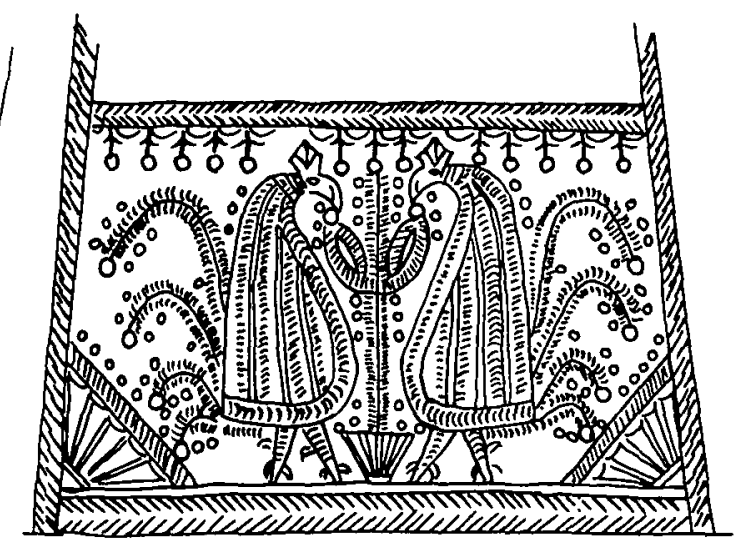

(b)

Fig. 3. (a) Detail of prialka-terem, Iaroslavskaia guberniia. After Taranovskaia and Mal'tsev, plate 25. (b) Detail of prialka-terem, Iaroslavskaia guberniia. After Voronov, Krest'ianskoe iskusstvo, p. 45.

facing a tree. But these tableaux began to be intruded upon by the natural world. Little suns pierce the walls, blaze from between curtains, flash from under tables and stools. The tea drinkers sit holding leafy branches. Fronds and florets sprout from the table and dangle from the ceiling. More sprigs shoot up from the tower, or what is left of it, and little birds perch on the spire. Like castles in a jungle, the urban structures, the aristocratic chambers with their classic decor, are gently but irresistibly pervaded with sunshine, vegetation, and flowers.

In this way the peasant imagination gradually, without effort, digested urban experience. ${ }^{8}$ The Yaroslav teremki show that the old images had not lost their resilience and vitality. Far from encumbering the peasant artist, they gave him the power to decompose startling urban novelties into the world he understood.

But peasant art, geared to generations, turned slowly. Most craftsmen, as Zhegalova has shown, stuck to the designs worked out in youth. ${ }^{9}$ Although new impressions were raining in upon the peasantry throughout the nineteenth century, not many found their way into peasant art. ${ }^{10}$

By the early twentieth century, however, the old forms were losing their

8. For another example of this process, compare the "artistic folklorization" of the rusalki in the nineteenth-century Volga housecarving. V. M. Vasilenko, Russkaia narodnaia rez'ba $i$ rospis' po derevu XVIII-XX vv. (Moscow, 1960), pp. 44-46.

9. Zhegalova, p. 136.

10. See the 1863 Yaroslav prialka in the State Historical Museum, depicting a train chugging out of a station, or the mid-century series by an unknown master, with fashionable "classical" scenes elegantly carved in low relief (for example, the 1868 prialka in Sokrovishcha, illus. 137-38). 
grip. They could no longer contain the rush of new experiences. The Russian village was coming apart, as peasants were pulled further into industry and modern institutions. Finally two decades of war and social upheaval, culminating in collectivization, destroyed the autonomy of the villages, leaving the peasants helpless to respond as a group to their condition. Peasant art, an outgrowth of collective peasant experience, soon withered away. The waning of the ancient forms did not free the peasants for a new artistic flowering. It signaled the demise of that peasant culture which had held its own for centuries, only to be finally overwhelmed by the urban world.

The old images were not the whole of peasant creativity, but they anchored it. They were like a man's native village, which he might leave for the better part of his life, yet belong to always. These forms remained at the heart of the peasants' apprehension of the world. No history of peasant art is possible without understanding them.

By the nineteenth century, the old images in peasant art did not come clothed in explanations. When questioned by educated observers, the peasant could not or would not explain them: ${ }^{11}$ Possibly these pictures were never put into words, for words do not blend together in an unbroken circle of meaning as these images do. Most likely they arose as a way of directly visualizing belief. If so, the old pictures are no more mute than they ever were. And though the historian has no hieroglyphics to assist him, the images have also not been shattered or eroded. Renewed by each generation of peasants, they come down to us pristine.

First, the sun. A picture of the sun can hardly be misunderstood. The question is how deeply can we comprehend that image? It is easy to take the sun for granted, to note the "solar disks" in Russian peasant art, and pass on. But then the sun stays flat; the big northern prialki, carved with many suns, remain blank and dumb.

"Solar disk" is not a term peasants would have understood; we have missed what impelled them. We have to try to see with their eyes. They did not see a circle. They saw a full sun high above them, a huge clome on the horizon, segments of light from trees and houses, rays of sunlight shooting out from behind clouds. They saw no disk, but a mass that flashed and whirled and blazed, and in the flickering light of their oil lamps and tapers, their carved suns also sparkled. For them the sun was everywhere, rising and sinking, warming and fading. They saw a procession of suns, following in a cycle that made days, and years, and time. They were constantly turned to the sun, for they lived mainly out of doors, depended on sunlight and heat, fed on plants the sun grew and ripened. June and November, sprouting and harvesting,

11. M. P. Zvantsev, Nizhegorodskaia rez'ba (Moscow, 1969), p. 14. 


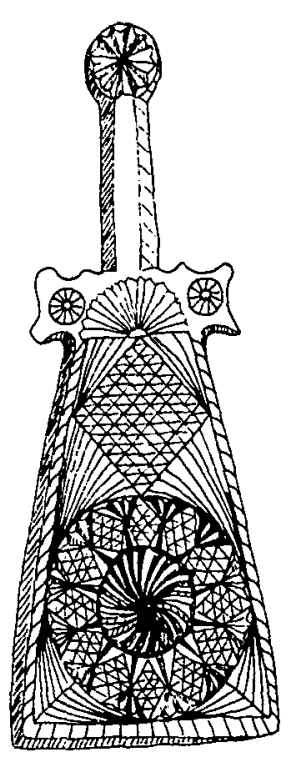

(a)

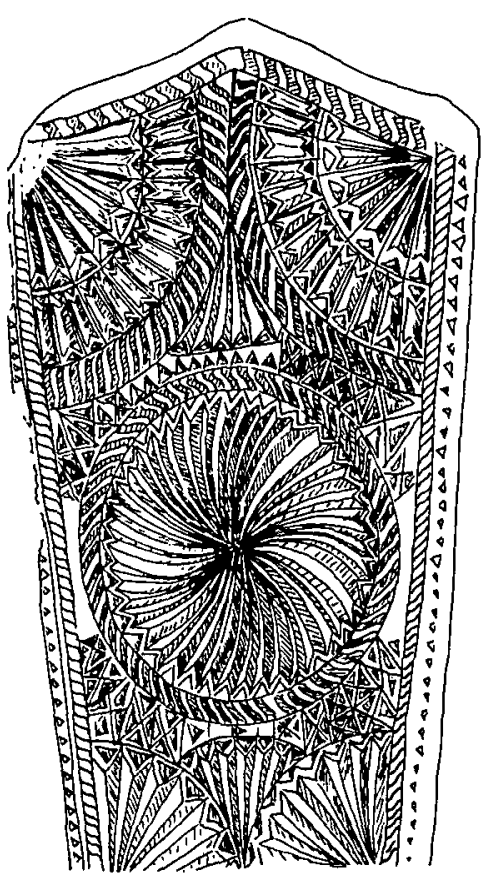

(b)

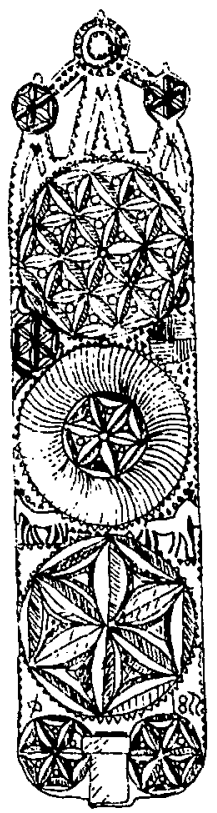

(c)

Fig. 4. (a) Valek, probably Yaroslav region. After V. M. Vasilenko, Russkaia narodnaia rez'ba i rospis' po dercone XVIII-XX vv. (Moscow, 1960), p. 148. (b) Rubel', Vladimir region. After Vladimir-Suzdal'skii muzei zapovednik [G. Shamrai], "Narodnaia dekorativnaia rez'ba po derevu" (Vladimir?, 1969). (c) Prialka, 1855, Purnema, Onega peninsula. After N. V. Mal'tsev, "Ornamental'naia rez'ba po derevu na Onezhskom poluostrove," in Russkoe narodnoe iskusstvo severa (Leningrad, 1968), p. 73.

basking and shivering, color and blindness-year after year in these experiences the peasants saw the sun. They saw the exploding energy that Blake and Van Gogh saw. They saw the source of life on earth.

To say that the sun in peasant art is a symbol is to set up a screen where none existed. The peasants could not easily gaze at the sun. Its brilliance hurt their eyes; labor bowed their heads. But through the intricate carvings, they could look at the sun to their heart's content. Pictures of the sun were a way of discharging an emotional debt, built up over years of utter dependence on solar light and warmth. They were a heightening of attention and a simple expression of reverence.

The sentient multitude of flowers, animals, and birds portrayed in peasant art expand the central vision of the sun. They embody the streaming solar energy. Flowers were mostly abstract, possibly because the artist, working usually in winter, had only the memory of summer blooms before him. Still, the painted blossoms possess a vitality-the twining, unfolding vigor of living plants-which distinguishes them from the set floral motifs of urban decorative art. 


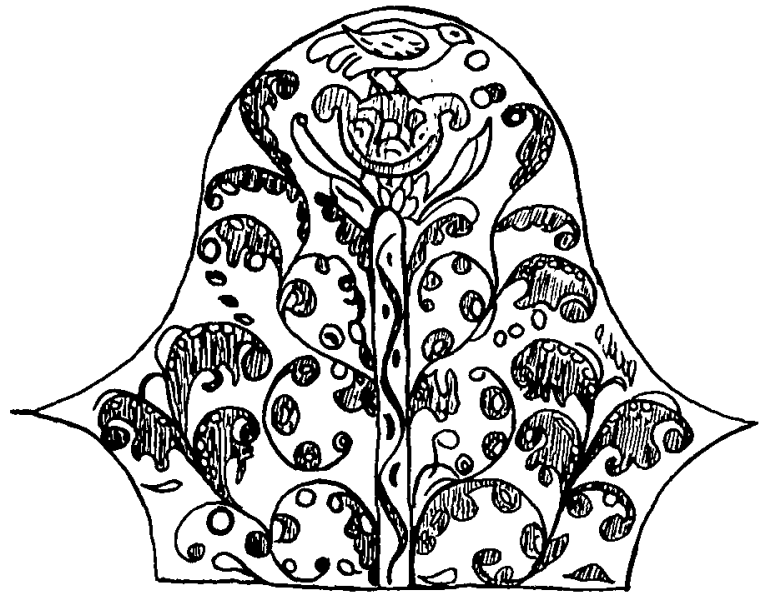

(a)

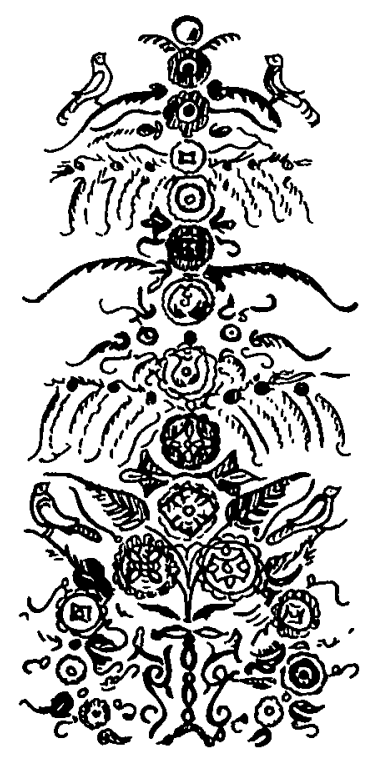

(b)

Fig. 5. (a) Detail of prialka, early twentieth century, Puchuga, Northern Dvina, Arkhangel'skaia guberniia. After Arbat, Puteshestviia, illus. following p. 48. (b) Mural, sclo Topol'noe, Soloneshenskii raion, Altai. After Iurii Arbat, Russkaia narodnaia rospis' po derevu (Moscow, 1970), p. 106.

Rootless radiant blossoms easily merged with the image of the sun. On late nineteenth century prialki, the meticulous carvings of the sun were mostly replaced by brightly-painted flowers. But where the flowers are carefully drawn, the solar image clearly reemerges. Living surrounded by flowering plants, the peasants continued to see in them the life-creating energy of the sun. In a more earthy form, they shared Shelley's vision: ${ }^{12}$

Life, like a dome of many-colored glass,

Stains the white radiance of infinity.

Birds and animals were nearly as prominent in peasant decoration. The peasant artist put little songbirds everywhere in treetops and flowering foliage. He caught the distinctive shapes of water and game birds with laconic accuracy. But his favorite birds were poultry, especially roosters. He drew them in their proudest moments, strutting and crowing. By stressing the arch of neck, the plumed tail, he magnified the scrawny backyard cock into an almost regal bird.

12. The contact between Romantic and peasant art is more than tangential (as the Romantics theniselves divined). The Romantic artist, intellectually and emotionally, was trying to escape the walled city, which shut the peasants out. But the Romantic, beginning with his individual consciousness, sought a transcendent fusion with the universe which would leave his self unimpaired. That was one worry Russian peasants were free of; they would not have understood the regret in Shelley's "stains." 

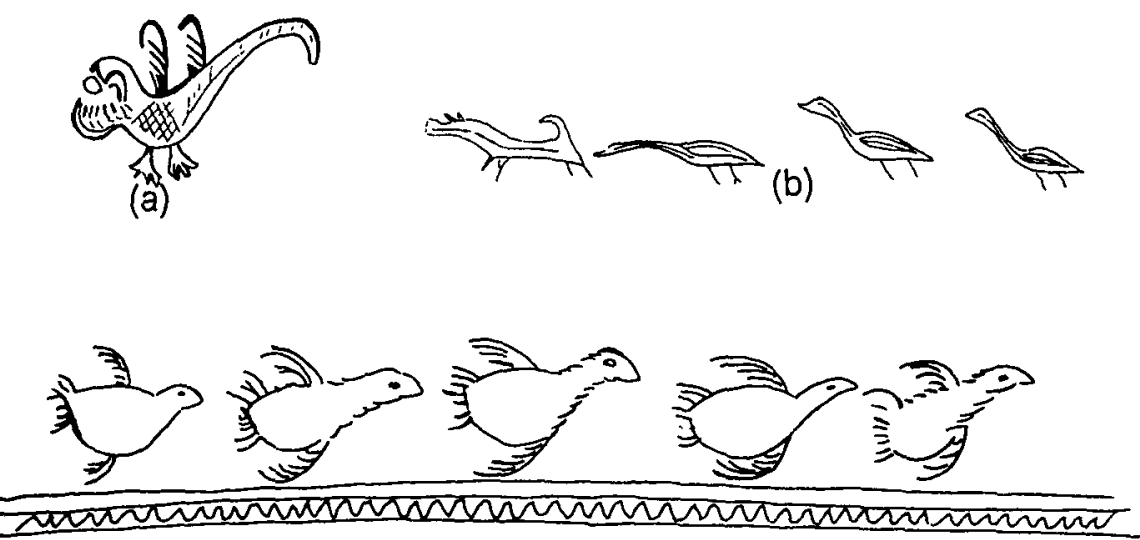

(c)

Fig. 6. (a) Goose alighting, detail of prialka, Palashchel'e, Mezen', Arkhangel'skaia ;uberniia. After Arbat, Puteshestviia, illus. following p. 80. (b) Detail of dontse (prialka sase), Nizhegorodskaia guberniia. After Voronov, Krest'ianskoc iskusstvo, p. 49. (c) Water birds, apparently Alcidae sp., detail of prialka, Palashchel'e. After Taranovskaia and Mal'tsev, plate 54.

Along with idealized domestic fowl, the peasant artist portrayed a fabulous bird, the ptitsa-sirin. This creature, with the body and plumage of a bird, and the head, sometimes the breasts, of a woman, is known from Kievan times, where she turned up on pottery and cloisonné. ${ }^{13}$ In later centuries she joined various heraldic animals in stone reliefs on churches. ${ }^{14}$

From the seventeenth century the Sirin remained a favorite image, not only in purely peasant art; but in Russian folk culture generally. She frequently posed for popular prints (lubki). A set caption explained that the Sirin dwelled in the east, in paradise, but occasionally flew out to earth. singing so beautifully of future bliss that any mortals who heard her were smitten senseless and died. ${ }^{15}$

Despite the allusions to God and the saints in these captions, written no doubt for the censors of the Holy Synod, the Russian Sirin is clearly sister to the sirens of classical mythology. ${ }^{16}$ She also bears a family resemblance to

13. Z. P. Popova, "Raspisnaia mebel'," in Sokrovishcha, pp. 50 and 52; Tamara Talbot Rice, A Concisc History of Russian Art (New York, 1963), p. 92.

14. See the decorations on the Church of St. George (1120-28) at Yuriev-Pol'skii (Rice, p. 33), and on the gates of the Church of the Resurrection in the Forest ( $1 a$ Dcbrc) at Kostroma (1652) in V. Ivanov, Kostroma (Moscow, 1970), pp. 84-86, 98-101.

15. D. Rovinskii, Russkiia narodnyia kartinki, 5 vols. (St. Petersburg, 1881), 1:48487, 5:140-41; Iu. Arbat, Puteshestviia za krasotoi (Moscow, 1966), illus. following p. 48.

16. The Greek sirens were originally birds. Those portrayed beguiling Odysseus on a fifth century B.C. vase from Vulei look almost exactly like the Russian ptitsy (Michael Grant and John Hazel, Gods and Mortals in Classical Mythology [Springfield, Mass., 


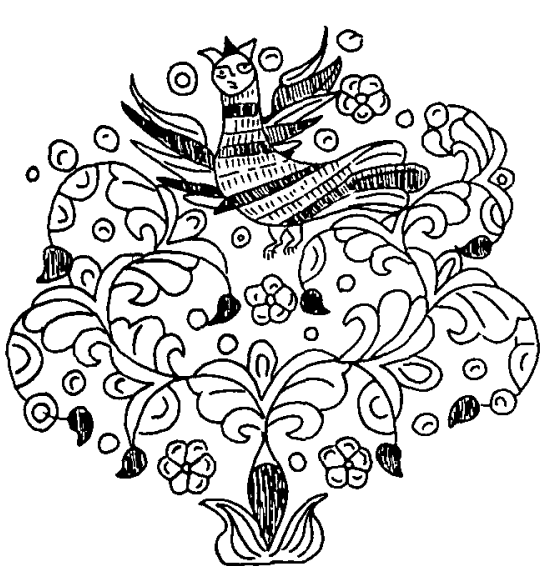

(a)

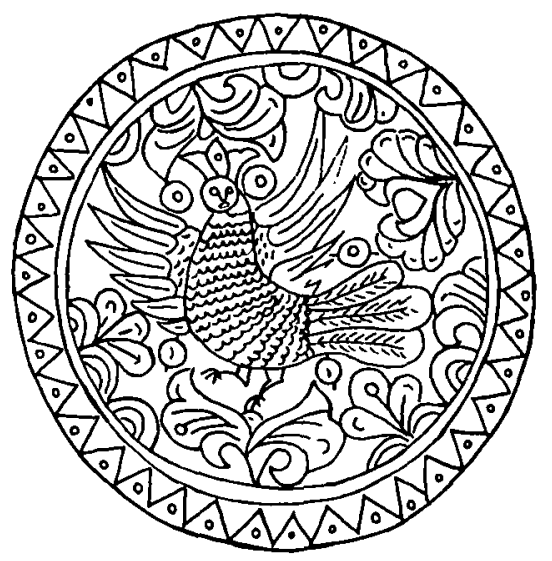

(b)

Fig. 7. (a, b) Details of prialki, Permogor'e, Northern Dvina, Vologodskaia guberniia. After Arbat, Puteshestriia, illus. following p. 48.

the mermaids who tempted the northern European sailors. Indeed in the carvings on peasant houses along the upper Volga, inspired by the decorations on river barges, the Sirin was often replaced by a mermaid, known as rusalka or beregin'. ${ }^{17}$ These names take us to the roots of this widespread image in Slavic folk culture. ${ }^{18}$ The rusalki and beregini were water maidens who dwelled in rivers and streams, often thought to be the restless spirits of unchristened children and young women who had drowned. In early summer these nymphs

1973], p. 367). For classical representations of the sirens, see John Pollard, Secrs, Shrincs, and Sircns: The Greek Religious Revolution in the Sixth Century, B.C. (South Brunswick, N.Y., 1965), pp. 137-41.

17. For an indication that the ptitsy-siriny and rusalki were related, the writer $B$. V. Shergin recalls from his native Arkhangelsk province gingerbread (prianniki) depicting either ptitsy-siriny or rusalki, there called beregini (recounted by Vasilenko, p. 40). They were also called faraonki, from an obscure but tenacious pseudo-Biblical legend, which identified them with the Pharoah whom Jehovah had drowned in the Red Sea, or with the Pharoah's daughter. It is hardly possible to trace the twists of popular imagination which resurrected the persecutor of the chosen people as a mermaid. Possibly the association was with the compassionate princess who had found the baby Moses fioating in the rushes, or conceivably the Russian peasants felt some affinity between their own river nymphs and other pagan spirits submerged by the mighty Judaeo-Christian God. particularly since the story, according to Vasilenko, "arose in Old Believer circles" (Vasilenko. p. 36).

18. Zvantsev, pp. 14-16, illus. 63-86, and especially Vasilenko, pp. 35-52. On the classical derivation of the word rusalka and the solstice ceremonies associated with her, see S. A. Tokarev, Religioznye verovianiia vostochno slavianskikh narodov XIX-nachala $X X$ v. (Moscow, 1957), pp. 87-94; V. Ia. Propp, Russkie agrarnye prazduiki (Leningrad, 1963), pp. 77-81. 


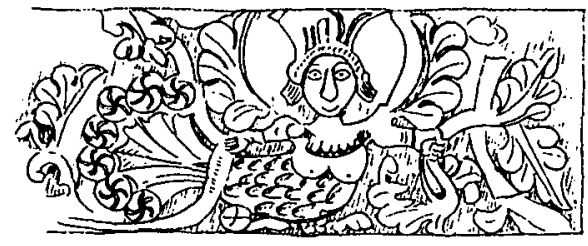

(a)

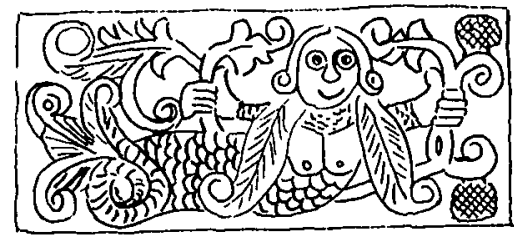

(b)

Fig. 8. (a) Detail of house carving, Middle Volga, probably Nizhegorodskaia guberniia. After Voronov, Krestianskoe iskusstvo, p. 12. (b) Detail of house carving, selo Shchekino, Nizhegorodskaia guberniia. After S. Agafonov, Gor'kii, Balakhna, Makar'cv (Moscow, 1969), p. 149.

emerged and romped through forests and fields, grass and grain springing up lushly in their tracks.

The rusalki, like mermaids and sirens, were equivocal creatures. Youthful and lovely, with long bright hair and beguiling voices, they threatened to ensnare lone mortals who encountered them. Perhaps these playful spirits embodied memories of a time when people wandered hunting and gathering, before they were peasants rooted to one place and fastened in a chain of agricultural toil. Significantly, the rusalki were exorcised in June, just before the gladness of early summer gave way to the stradnoe vremia of haying and reaping. In a ceremony similar to the other spring festivals (maslenitsa, Troitsa, Ivan Kupala, funerals of Kostroma or the cuckoo ${ }^{19}$ ), the girls and women fashioned a straw rusalka, clothed in finery or ribbons, and with laughter, song, and dances conveyed her out of the village, strewing her on the field to encourage the heading rye, or casting her back into the water. ${ }^{20}$

The joyous mock funerals of the rusalki, like the captions for the Sirin prints, reflect the ambivalence the peasants felt toward such creatures. In one print the assembled narod are blasting away at a lovely Sirin with a cannon. ${ }^{21}$ In some festivals, the escort divided into two groups, mourners and mockers, who struggled for possession of the effigy, reuniting in general merriment when she was finished off. ${ }^{22}$

19. Propp, pp. 68-77, 81-89. All these ceremonies except Lent fell in the solstice period between the week before Troitsa (rusal'naia nedelia) and the end of June (Pctrov $\left.d e n^{\prime}\right)$. It should not be supposed that they were all observed even ywhere. Each locality, even each village, elaborated its own unique seasonal festivals.

20. Propp, pp. 77-81; Tokarev, pp. 90-91; Vasilenko, pp. 49-54.

21. Iu. Ovsiannikov, Lubok: Russkic narodnye kartinki XVII-XVIII vv. (Moscow, 1968), p. 81.

22. Propp, pp. 81 and 88 . 
A similar mockery surfaces in the pipe-smoking rusalki on a few of the Volga friezes. But in most peasant woodcarving and painting-done of course by men-the Sirin or rusalka is shown in a benevolent light. The Sirin is invariably portrayed crowned, hovering in the air or alighting on a tree, as if she had just flown down from her heavenly abode. ${ }^{23}$

At Permogor'e, where she was a favorite subject, the Sirin usually floats benignly over scenes of domestic well-being. Sometimes she poses inside the sun in all her splendor; at other times with flopping wings and comblike crown she hobnobs with the local chickens; only her face gives her away. On certain prialki it is possible to see a progression from scrawny pullets through showy roosters to the paradise bird.

The Permogor'e artists painted the most realistic pictures of everyday peasant life. It seems strange that they included the Sirin bird in their scenes, almost as a member of the family. That strangeness should tell us that the peasants did not see the world as we do; they did not feel obliged to draw a line between reality and fantasy. To them, the ptitsa-sirin belonged to the natural world.

Common birds, like roosters, also had their fabulous side. At times they displayed a color and verve that in Permogor'e painting literally raised them out of the barnyard, joining them to the Sirin and the sun. And this reveals another peculiarity of peasant imagination: the urge to associate far overrode the impulse to classify. Peasant art, lore, and ceremony are an unending spider web of associations, as fecund and fragile as dreams.

No being had a sharp boundary; each thing tended to flow over into something else, and the more creatures were charged with solar energy, the more fluid they became. The rusalki and siriny radiated a freedom, beauty, and pleasure too strong for single mortals to bear. Only the village collective, through its organized ceremonies, could harness this unearthly energy: lead the rusalki out to fertilize the grain; call down the Sirin to bless the marriage union.

Returning to the stream of peasant imagination-but shifting from birds to mammals-natural, exotic, and fabulous creatures mingle. The deer, dogs, cows, pigs, goats, cats that populate the background spring from a few sure lines, drawn by those who knew them thoroughly. Even unicorns, griffins, and other heraldic beasts, though traced at times from patterns, possess a rough vitality, the gift of artists who lived with animals and respected them.

Of the exotic animals, only lions appear with any frequency. The peasants pacified them. They smile down from the Volga cabins, their pliant

23. Ovsiannikov, p. 80: "Vremenem vyletaet i na zemliu $k$ nam." 


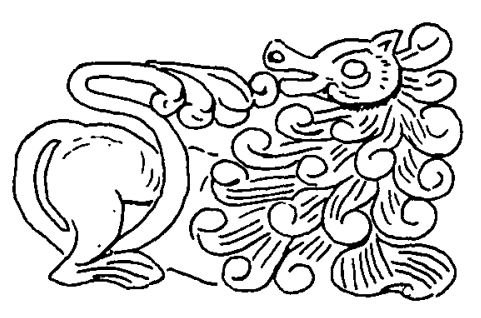

(a)

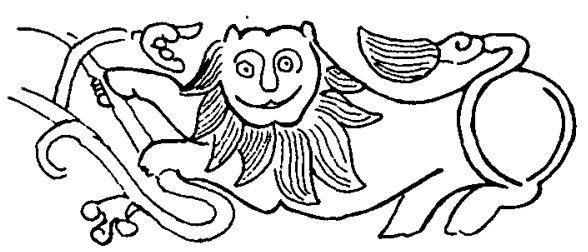

(b)

Fig. 9. (a) Detail of house carving, derevnia Sharypovo, Gorodets district, Nizhegorodskaia guberniia. After Arbat, Puteshestviia, illus. following p. 128. (b) Detail of house carving, probably Vladimirskaia or Nizhegorodskaia guberniia. After [Shamrai], Narodnaia dekoratimaia rez'ba po derevu.

bodies twisted like vines into the narrow spaces on the boards, their tails blossoming, their manes spreading like rays of sun or luxuriant foliage. Though tamed, the peasant lions radiate vigor and energy. And this may have been part of the appeal of strange and wonderful creatures - they revealed the boundless creativity of life.

But the most important animals in peasant art were horses-or better, steeds (koni). Dostoevskian nags never appear; only spirited mounts and carriage horses. The fascination with horses spread beyond decorative art into every corner of peasant life. On old Russian cabins, the butt end of the scooped log that capped the roof (okhlupen') was carved into a horse's head (konek). The carved heads apparently replaced horse skulls, which the early Slavs had once fixed to the rooftop. ${ }^{24}$ In places in the upper Volga region the top log was still sometimes called the "skull log." ${ }^{25}$ Smaller kon'ki cropped up everywhere: on barn roofs, apiaries, cemetery and memorial (obetmyi) crosses; porch newel posts, benches, partitions, flareholders (svetsy), looms and spindles; combs, mirrors, cleavers, salt-holders, bowls and cups for ceremonial brew. ${ }^{26}$

In pictorial art the peasant drew a proud horse-neck and tail arched, foreleg raised high-champing at the bit or racing away. Often the horses were painted white or red and clad in fancy trappings to emphasize their

24. A. Belov, "Kon'ki: Istoriko-etnograficheskii ocherk," Zhivopisnain Rossiia, 1902, no. 98, pp. 556-58; V. V. Stasov, "Kon'ki na krest'ianskikh kryshakh," Sobranie sochinenii, 3 vols. (St. Petersburg, 1894), 2:105-14.

25. S. K. Zhegalova, Russkaia dereviannaia res'ba XIX veka: Ukrasheniia krest'ianskikh izb Verkhnego Povolsh'ia (Moscow, 1957), p. 38.

26. See, for example, Arbat, pp. 64ff., pp. 176ff.; M. I. Mil'chik, Po bercgam Pinegi i Mezeni (Moscow, 1970), pp. 21, 35, 108, 120, 135 ; Dintses, pp. 467-68; S. M. Prosvirkina, Russkaia dereviannaia posuda (Moscow, 1957), p. 143. 


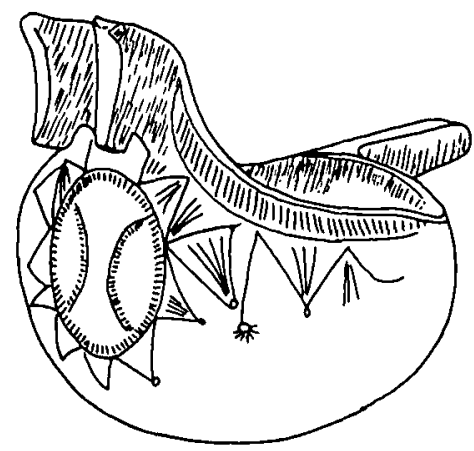

(a)

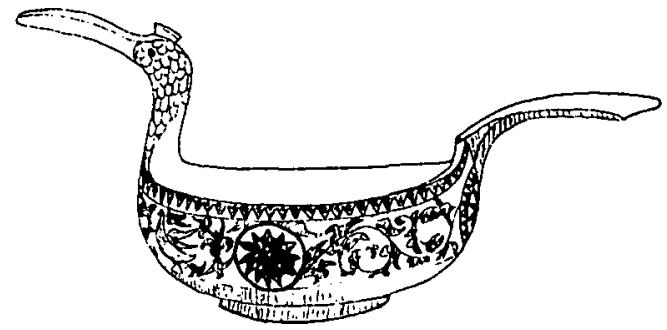

(b)

Fig. 10. (a) Kovsh, Nizhegorodskaia guberniia. After Voronov, Krest'ianskoc iskusstvo, p. 50. (b) Kovsh, Permogor'e, Northern Dvina, Vologodskaia guberniia. After Musei narodnogo iskusstva (Moscow, 1968).

remove from the dull bony beasts who dragged carts and plows. The lines of these epic animals were not left to chance. Birds might be lumpy, human figures awry, but ungainly horses are rarely to be seen. All strongly resemble the horses of icon art, especially the folk icons of northern Russia. ${ }^{27}$ In other words, the portrayal of horses was stylized to stress certain key characteristics: strength, mobility, verve.

We now happen on a curious link. At their most stylized, horses come to resemble birds, and vice versa. The two animals were paired with each other: bircls carved on rafter ends with a konek on the roof, a horse on one side of a Gorodets dontse, a matching bird on the other. At times the two almost fuse into one archetypal animal. Evidently peasants sensed qualities in horses and birds-pride, flamboyance, free movement-which set them above the other domestic creatures. ${ }^{28}$

Both animals, moreover, shared a special relationship with the sun. In the clepth of winter and in the dark of every night, the crowing cock heralded the return of the sun, a fact made much of in peasant lore and custom. ${ }^{29}$

There was also the widespread legend, dating back perhaps to neolithic times and persisting in Russian folklore, that the sun was carried across the sky in a horse-drawn chariot. ${ }^{30}$ Descending into the Western Ocean, the

27. See especially the numerous icons of Flor and Lavr, and of St. George and the Dragon; E. M. Smirnova, Zhivopis' oboncsh'ia XIV-XVI vekov (Moscow, 1967), pp. $72,88,174$.

28. Dintses, p. 475 .

29. Tokarev, p. 55.

30. The finest early representation of this legend is the elegant sun chariot from 


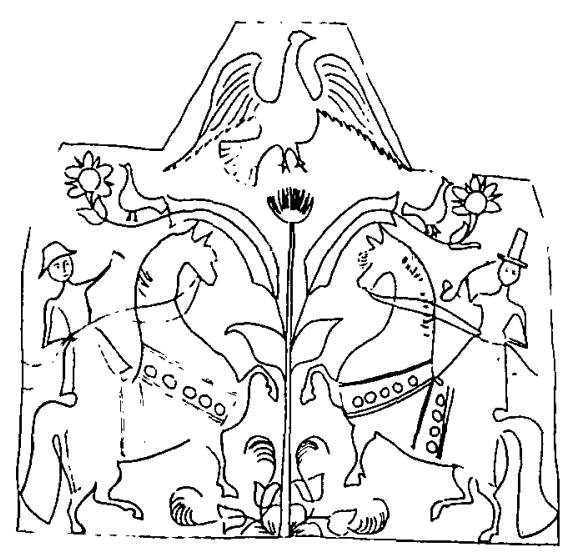

(a)

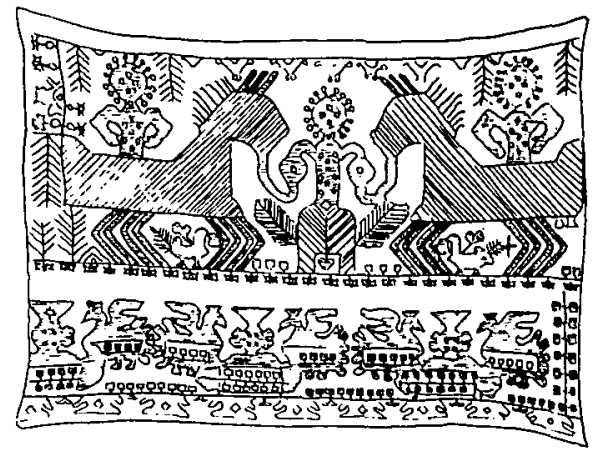

(b)

Fig. 11. "Homage" motif, classic forms: (a) Dontse, Gorodets district, Nizhegorodskaia gubernia. After Voronov, Krestianskoc iskusstzo, p. 37. (b) Embroidery, North Russia. After T. M. Razina, Russkoe narodnoc tvorchestvo (Moscow, 1970), p. 137.

horses were transformed into water birds, who drew the sun around to the dawn. ${ }^{31}$ In Russian peasant art this legend is illustrated by the elegant wooden drinking boats, with prow-handles shaped like the heads of horses or water birds and floral suns on the side, ${ }^{32}$ and by rough-hewn red toy carts, each loaded with a sun-wheel. ${ }^{33}$

As birds and horses, pared down to visual epithets, converge, they move away from the peasant's awareness of the natural world. That awareness centered on the sun. The artist's first concern was to evoke the experience of sunlight and the burgeoning of life beneath it. But the cock-steed silhouettes lose the look of natural creatures. They take on the cast of symbols, standing for something present but not visible.

Trundholm (ca. 1300 B.c.) now in the Danish Museum, The conveyance of the sun by chariots and bird-ships is abundantly represented in rock carvings and metalwork from the Scandinavian Bronze Age. See Peter Gelling and Hilda Ellis Davidson, The Chariot of the Sun (New York, 1969). For additional evidence on prehistoric sun worship see E. Anati, Camonica Vallcy (New York, 1969). By comparison, occasional references to sun chariots in classical mythology, though well-known, are much less compelling; in the Mediterranean, such ideas were "swamped in a sea of Hellenism" (Gelling and Davidson, p. 123). Still, in the irrepressible idolatry of Palestine, sun chariots were prominent enough to provoke Jehovah's wrath (2 Kings 23:10-11).

31. Vasilenko, pp. 48-51, 97-99; Prosvirkina, pp. 32-33.

32. See also the bowls illustrated in O. V. Kruglova, "Severodvinskie rospisi," in Russkoe narodnoe iskusstwo severa (Leningrad, 1968), p. 32; Voronov, pp. 50-51 ; Razina, p. 47.

33. Dintses, pp. 479 and 482 . 


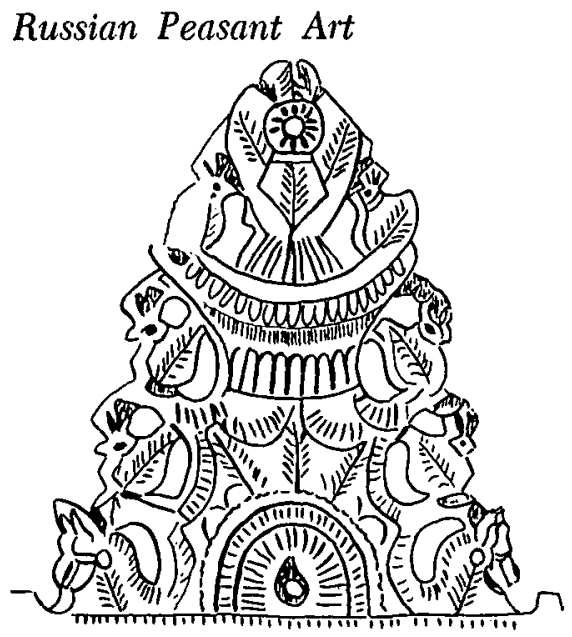

(a)

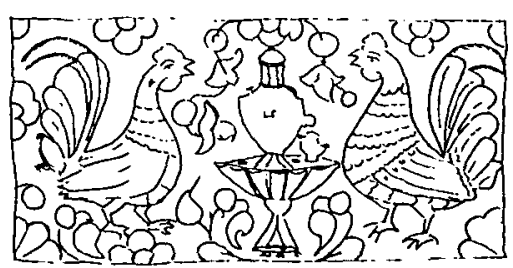

(b)

Fig. 12. "Homage" motif, occluded variants: (a) Top of prialka-terem, Jaroslavskaia guberniia. After Taranovskaia and Mal'tsev, plate 25. (b) Detail of prialka, Permogor'e, Northern Dvina, Vologodskaia guberniia. After Voronov, Krest'ianskoc iskusstzo, p. 94.

As symbols. stallions and roosters lead into the second circle of images. Here the dominant form is a vertical figure, flanked by two lower creatures. Traditionally the central figure was a woman with upraised arms; later it was often a tree.with flowers, fruit, or birds. The adjoining creatures might be humans, especially mounted horsemen, horses, or rooster-birds. ${ }^{34}$

What are we to make of this basic image as persistent as it was mutable? The archetypal quality of the animals and other figures involved suggests that we are looking not at a picture of natural objects. but at a representation of something invisible though no less real. To the peasants, the one reality which could rival nature in importance was society and human relationships.

What does this image reveal about the social world of the peasants? To begin with, it is a picture of harmony, not conflict. The design is balanced, the figures in repose. They appear to be involved in a ceremony. a ceremony of obeisance or homage.

Homage involves a willing submission to an authority deemed legitimate. In this respect the image is curious. For the figure in the position of power is a woman, or a flowering tree with birds. Those doing reverence are commonly men, often armed men on horseback. Thus the pattern of authority so painfully conspicuous in Russian peasant society is reversed; men do homage to a woman, and analogously, roosters and stallions yield up their speed and power before a flowering tree.

34. Ibid,, pp. 470-71, 473. 
But neither woman nor tree is treated as final authority. There also is an air of being open to something from above: the ancient goddess raises a chalice, the trees open their blossoms, the birds their wings. And often enough the higher power deigns to show its face: the sun, or some solar avatar, shines down on the whole scene. Thus not only is the ordinary social order turned upside down; it is revealed to be a part, a subordinate part, of the greater natural order.

At first glance, the image also invites a sexual interpretation. The central form appears phallic, aiming toward a solar womb. Yet this "phallic" shape is often represented as a flower or a woman, with male figures-horsemen, stallions, roosters-in attendance at either side. Again the facing pair may be a couple: bride and groom, husband and wife.

Peasant art, like village society, kept the differences between men and women continually in view. ${ }^{35}$ Yet these differences were regarded less as an absolute dichotomy than as the phases of a single vital rhythm. The phallus was called forth by woman, dissolved into her, was again revived by her, and new males given birth. The sense of male-female as an oscillation of sexual energy is echoed, in fact experienced, in peasant designs. Male and female aspects, both explicit and subliminal, are intermingled and superimposed, so that the attention of the viewer swings from one to the other. The sexes are visibly distinguished only to be fused in a living union.

Significantly, scenes of a harmonious balance between man and woman decorated especially those objects-prialki, embroidered towels, ceremonial dishes-closely connected with the work of women and with the marriage ceremonial. The continual spinning-courting bees which absorbed village youth from October on, the consecutive fall festivals devoted to a female goddess in Christian disguise, culminated in marriage and the re-creation of human life on the one hand, and, on the other, in solstice and the rebirth of the life-giving sun. ${ }^{36}$

Peasant art thus served in a great undertaking which required as intense a concentration of human energies as planting and harvesting the crops. In this effort women took the lead: The ceremonies they created were partially wishful, conjuring sunlight and fertility, but they were much more. They were also practical, a carefully orchestrated perpetuation of human life despite the cold and dark. The winter marriage was a human triumph over death. The undertones, of sexuality in the image of the goddess and her guardians reflect the fact that this was an emblem of sublimated sexuality,

35. Compare the deliberately asexual quality of Christian art, in Russia and elsewhere.

36. See the brilliant description of the fall ceremonials in V. I. Chicherov, "Zinniii kalendar'," in his Zintmii period russkogo narodnogo zcmledcl'cheskogo kalcndaria XVI$X I X$ vekov (Moscow, 1957), pp. 25-63. 


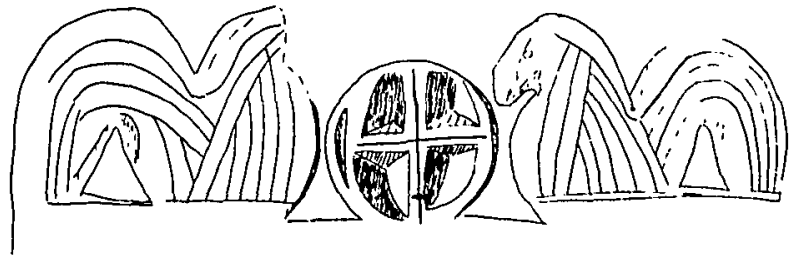

(a)

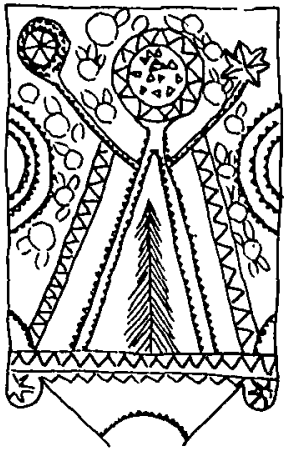

(b)

Fig. 13. "Homage" motif, spontaneous variants: (a). Top of prialka, dercrmia Iarygino, Staritskii uezd, Tverskaia guberniia. After Taranovskaia and Mal'tsev, plate 20. (b) Detail of prialka, Kenozero, Kargopol'skii uczd, Olonetskaia guberniia, ibid., plate 37.

of sexual impulses put to social uses to create family and social order. The pictures were not idle: the scenes on distaffs at the courting parties illustrated how young people should behave.

Finally, we should not ignore the political implications in the homage motif. In peasant art it was usually not peasants who paid homage to the goddess or flowering tree, but men at arms: the mounted warriors, nomads or pomeshchiki, who for two thousand years had controlled peasant society on the Russian plain.

The peasants thereby denied that their rulers ruled the earth, or even established the social order. Proud and powerful as the lords appeared to be, they too paid reverence to the force of life. ${ }^{37}$

Should we conclucle that the peasants were iclealists. that they portrayed their society-family, village, state-not as it was but as they wanted it to be? Or should we say that they saw social relationships not as they seemed to be, but as they truly were? For peasant art can hardly be called Romantic. It does not at all have the bitter sense of schism. the spurning of the corrupt world at hand while pining for another, brighter realm. There is no accusation, no despair.

Peasant art is invariably bright. serene, and joyous-zhizneradostnyi, as Russian observers aptly say. Considering the squalor of Russian village life, such a vision was an extraordinary cultural tour de force. Compare peasant art with the abysmal existence sketched by Chekhov in The Pcasants. In conditions which struck the sensitive educated observer as utterly degrading, peasants were able to perceive life as joyous.

37. The horsemen were often shown impregnating a female symbol or trampling their enemies (Ambroz, pp. 69-72). Thus the whole design stressed male sex and power, zwithin the social and natural balance. 
The cultural vitality of the Russian peasantry shows up still more sharply in the ability of peasant artists to assimilate alien elements. In drawing their masters, the peasants recorded with laconic accuracy, almost as in a cartoon. the changing fancies of the elite in arms and conveyance, costumes and poses. The mansions of the boyars, classical drawing rooms, the clock tower of Petropavlovsk and the paddle-wheel steamers all make their appearance on peasant prialki. When urban fashions began to trickle into the village in the nineteenth century, samovars and chandeliers assumed the place of honor in the traditional homage scene. And the peasant para came to the vecherinka in their boughten finery; he in his patent leather boots, she in her kerchief and ribbons.

As suggested earlier, the attention the peasants devoted to the culture of the elite may be read two ways. One can say, as is usually done, that nineteenth-century peasants were fascinated by the changing world around them, and tried to portray it realistically. And undoubtedly peasant art often reflects the wonder of the rustic, the admiration of the muzhik for his betters.

But this admiration was not abject. The village artist looked closely at only a few elements of the high culture, and he deliberately arranged these in the old designs. He did not show peasants bowing down to their masters, but those warriors reined in before the tree of life. Marveling at tower and steamer, he saw that the great clock and the pacldle wheel were only new faces of the eternal sun. The samovar that came onto the tables of the fortunate, radiating warmth and comfort, with its big belly and upraised arms - was it not a new incarnation of the goddess, awaiting the old reverence?

These contemporary scenes in ancient poses are ambiguous. Are the figures in an embroidered landscape water nymphs with flippers flanking a sacred tree, or cavaliers with wide sleeves boating in a park ?38 Was a modern world coming alive for the peasant within the husk of the old forms? Or dicl ancient beliefs endure, camouflaged in modern dress?3: Many clesigns contain an unavoidable ambivalence which the artists had no wish to resolve, which they lovingly cultivated and sharpened. This ambivalence was a source of the tension and power in peasant art, and part of the strength of peasant culture.

For peasants did more than register fashions and forces imposed on them from without. They persisted in seeing things their way; as part of the natural order. Art was one way of taking cultural control. Incorporating what attracted them into their designs. the peasants disarowerl the preten-

38. Dintses, pp. 472-73; Ambroz, p. 75.

39. Kievan figurines, dressed like the Scythian-Sarmatian earth goddess, suggest that the Slavic peasantry was long aocustomed to putting on the costumes of its rulers (Dintses, pp. 483-84). 
sions of the high culture. Despite new-fangled towers, ships, and fancy garments, the mounted warriors did not rule the universe. They brought their marvels as tribute and testimony to the tree of life.

The peasants dicl not openly reject existing authority: they sought to transcend it. Their response was essentially religious. But the religion involved was not Christianity. The virtual absence of Christian symbols in peasant art is striking. ${ }^{40}$ Peasant artists paid little attention to Orthodoxy, though many learned their skill painting icons or illustrating Old Believer manuscripts. ${ }^{41}$

What explains the indifference to things Christian, even among the avowedly pious? Apparently Christianity remained in their eyes a parochial though powerful cult, advanced by the state for its own ends. The peasants used this imposed faith to express reverence, to sanction certain rituals or to solicit aid from on high, without believing that Christianity had the sole view of the truth. The chapels, the icons, the carved wooden crosses and statues of North Russia show that Christianity had a place in the religious feelings of the peasants. But that place remained on the outskirts of the village, on the periphery of communal and family ceremonies. ${ }^{\mathbf{4 2}}$

In this light the Old Believer movement seems less of a dead end.43 Overt religious dissent in Russia was rooted in the web of counter-belief we have been exploring. The conjunction between known strongholds of Old Believer faith and conspicuous centers of peasant art (Borok, Semenov, Gorodets, Nizhnii-Tagil, the Altai) is indicative.

40. In the few instances where Christian themes enter peasant art, they are all but submerged, as in the needlework where an onion-domed chapel is deftly transformed into the familiar goddess (Dintses, pp. 488-90). In peasant art the substitution of Christian symbols never took hold. In pre-Petrine Russia, when cultural communication between peasant and high culture was still vigorous, the influence was more the other way: the artisans who made fine objects for the elite came mostly from the peasantry, and used peasant themes in their decorations (Rybakov, "Prikladnoe iskusstvo," p. 416).

41. See K. A. Bol'sheva, "Krest'ianskaia zhivopis' Zaonezh'ia," in Krest'ianskoe iskusstvo SSSR (Leningrad, 1927), pp. 53 and 57; M. A. Reformatskaia, Severnye pis'ma (Moscow, 1968), p. 16.

42. Peasants did not sharply segregate Christian and folk practices. In the spring ceremony of kumlenic, girls kissing through wreaths of braided birch also exchanged the crosses they wore as tokens of loyalty (Propp, pp. 129-32). But crosses and blessings by the priest served only to add additional authority to non-Christian beliefs.

Christianity also had no more than a toehold in the intricate marriage ceremonial, with which peasant art was closely connected. N. P. Kolpakova, "Otrazhenie iavlenii istoricheskoi deistvitel'nosti v svadebnom obriade Russkogo Severa," in Slavianskii fol"klor (Moscow, 1965), pp. 259-83.

43. "A living fossil," as Treadgold put it. His essay "The Peasants and Religion" articulates the prevailing pejorative attitude toward the Old Belief (Wayne Vucinich, ed., The Peasant in Ninetecnth-Century Russia [Stanford, 1968], pp. 72-107). 
Peasant artists often got training and assurance from the underground dissenter tradition. But inspiration flowed even more strongly the other way. ${ }^{44}$ To take only two examples, an elaborate print from the Vyg workshops shows the spiritual clan of Andrei Denisov as solar medallion flowers on a spreading drevo zhizni, with a pair of Sirin birds above, and the dissenter monastery-convent way below. ${ }^{45}$ Only the tiniest of crosses on the wooden domes mark the tie to Christianity. Equally instructive are the splendid Sirin birds painted by Vyg artists with the device Vidom $i$ Glasom"by appearance and by voice," that is, by beauty seen and heard. To clarify this image, one eighteenth-century panel juxtaposed the Sirin to an imperial eagle, captioned Silon i Zrakom-"by force and by vigilance." 46

The dissenter movement may be seen as a new, more conscious, and more bitter phase of the long struggle between Christian practices and folk belief. The rigid doctrine and ritual of the staroobriadtsy, so aggravating to the elite, served as a fortified barrier. Behind these defenses the religious awareness of the peasants pulsed with heightened brilliance.

To call this religion pagan is to think of it as sub-Christian, enmeshed in "primitive" rites and superstitions. The belief of the Russian peasants, as it gleams through popular art, belongs rather with the great Oriental religions, with their insistence on the oneness of life in all its forms and their reverence for life-energy. In the immediate sense this outlook counseled acceptance of things as they were, for everything that happened was part of life. But in the long run, stubbornly, slyly holding to this faith, the peasants refused to submit, for they denied the claim of the existing powers to absolute and rightful authority. And their view of life was after all the broader one. They observed the antics of the masters with benign clarity, putting them in their place in the great cycle of life that fused with the sun. It was the peasants, those temnye liudi, who were the more conscious of the world they lived in.

44. Peasant designs and symbols soaked into Orthodox Christian art too. See Ambroz, pp. 65-67. But Ambroz errs in stressing roundabout borrowings from "Eastern" art via Byzantium, and discounting the direct impact of folk images through peasant artisans.

45. Ovsiannikov, p. 78.

46. Popova, pp. 59-60, illus. 58-59. 